\title{
THE RESPONSE OF BITOT'S SPOT COMMUNITY VITAMIN A DEFICIENCY CONTROL PROGRAMMES IN NEPAL AMONG CHILDREN AGED 6-120 MONTHS
}

\author{
Tilden, R.L.; Pokhrel, G.P; Gorstein, J.; Pokhrel, R.P; West, K., Sommer, A. \\ and the Vitamin A Child Survival Project Team
}

\begin{abstract}
ABSTRAK
Tujuan dari studi adalah untuk mereview karakteristik dan faktor risiko untuk kasus Bitot's spot yang tidak memberikan respon terhadap terapi yang dilakukan pada saat diagnosis dan juga pada saat pemberian kapsul vitamin A dosis tinggi yang dilakukan enam bulan sekali. Faktor risiko ini dibandingkan juga dengan kasus bitot's spot yang sebelumnya diidentifikasi di tempat pelayanan kesehatan. Anak-anak yang terdaftar pada Nepal Vitamin A Child Survival Project diperiksa setiap tahun. Analisis dilakukan dengan membandingkan anak-anak dengan bitot's spot pada saat data dasar yang selanjutnya dipisahkan antara yang memberikan respon dan yang tidak memberikan respon terhadap terapi yang dilakukan, serta memperhatikan karakteristik menurut individu, rumahtangga, dan masyarakat. Analisis dilakukan dengan dua cara bivariate (chi square and ttest) dan multivariate (stepwise logistic regression). Dijumpai $62 \%$ anak dengan bitot's spot pada saat data dasar yang diperiksa 12 bulan setelah mendapat terapi kapsul vitamin A dan juga yang mendapat kapsul vitamin A dua kali setahun. Ditemukan faktor yang berpengaruh pada kasus bitot's spot yang tidak memberikan respon terhadap terapi vitamin A mempunyai karateristik pada umumnya laki-laki, kurus, tidak mendapat kapsul vitamin A yang didistribusi di tingkat masyarakat, dan bagian mata yang terkena bitot's spot (tempotal and nasal quadrant vs temporal alone). Untuk karakteristik tingkat masyarakat, kasus bitot's spot yang tidak memberi respon terhadap terapi kapsul vitamin A pada umumnya kasus yang tidak tinggal dalam lokasi studi, tinggal di wilayah dataran rendah, dan terutama di Kabupaten Parsa. Faktor risiko yang paling berpengaruh bervariasi berdasarkan tempat tinggal dan umur. Untuk anak yang tinggal di daerah pegunungan, kurang gizi (menurut $\mathrm{BB} / \mathrm{U}$ ) merupakan faktor risiko yang cukup signifikan. Untuk anak yang tinggal di dataran rendah, faktor risiko yang berpengaruh adalah cara intervensi, lokasi bitot's spot, jenis kelamin, lingkar lengan atas, dan mendapat kapsul sedikitnya dua kali. Untuk anak kurang dari 60 bulan faktor risiko yang terpenting adalah lokasi bitot's spot di mata, sedangkan untuk anak 60-120 bulan faktor risiko yang terpenting adalah tidak mendapat kapsul di lokasi studi, jenis kelamin, umur, ketebalan kulit, lingkar lengan atas, tinggi badan, berat badan menurut tinggi badan dan menerima kapsul kurang dari dua kali. Studi ini juga membenarkan faktor risiko berkaitan dengan kasus bitot's spot yang tidak memberikan respon terhadap terapi kapsul vitamin A di pelayanan kesehatan di Indonesia terjadi juga pada pelayanan yang dilakukan langsung ke masyarakat. Studi yang dilakukan di tempat pelayanan kesehatan di Indonesia menunjukkan $25 \%$ dari anak penderita bitot's spot tidak memberikan respon terhadap terapi yang diberikan. Sedangkan di Nepal, dari studi ini menunjukkan lebih dari 35\% kasus bitot's spot tidak memberikan respon terhadap terapi yang diberikan melalui disitribusi kapsul vitamin A di masyarakat. Studi ini tidak menunjukkan bahwa umur merupakan faktor yang berpengaruh untuk tidak memberikan respon, yang ditunjukkan adalah untuk kelompok umur tertentu faktor risikonya yang berbeda, dimana anak yang lebih muda lokasi bitot's spot pada mata menentukan akan memberikan respon atau tidak terhadap terapi yang diberikan, sedangkan untuk anak yang lebih tua faktornya adalah status gizi dan juga dosis vitamin $\mathrm{A}$.
\end{abstract}

Key Words: Non-responsive Bitot's spots, vitamin A deficiency, community intervention, Nepal, vitamin A supplementation 


\section{INTRODUCTION}

B itot's spots are a small cheesy or foamy ocular lesion overlaying a patch of rough or xerotic conjunctiva ${ }^{(1)}$. While these lesions do not affect visual acuity of children, this pathology is often associated with acute vitamin A deficiency ${ }^{(2)}$, increased risk of mortality ${ }^{(3)}$, and higher risks of diarrhea ${ }^{(4)}$. These ocular lesions are found in $0.5-3 \%$ of the children residing in areas where vitamin A deficiency is endemic.

Prior to the start of the child survival movement in the mid-1980's, the primary motivating factor for most governmental and donor agencies in addressing vitamin $\mathrm{A}$ deficiency was the control of nutritional blindness. Even though the effect of vitamin $A$ on reducing child mortality has become the primary concern in promoting the control of vitamin $A$ deficiency ${ }^{(5)}$, ocular eye signs of vitamin A deficiency particularly Bitot's spots, continue to play an important role in assessment of the problem within different populations, and as an indicator of program performance.

Bitot's spots are considered one of the more prefered indicators of vitamin A deficiency in community assessment. Bitot's spots are more common than corneal xerophthalmia, they are easier to diagnose than xerotic patches on the conjunctiva, and the presence of observable lesions is more reliable than maternal reports of night blindness. Laboratory measures of serum vitamin A do not reliably reflect body stores or bioavailability of vitamin $A$. The assessment of body stores of vitamin A can only be done using the relative dose response (RDR) or modified relative dose response (MRDR) tests, but both assessments are relatively expensive and time consuming making them inappropriate for wide scale community assessment. A promising clinical technique has been developed to measure the conjunctival cell changes associated with vitamin A deficiency called conjunctival impression cytology, but it has proven difficult to standardize ${ }^{(6)}$.

Unfortunately, not all Bitot's spots respond to vitamin A dietary supplementation. A recent study reported that over one quarter of all children observed with Bitot's spots did not show disappearance of the lesion after clinic based treatment and follow$u^{(7)}$. The term non-responsive Bitot's spots was used to describe these children in a study evaluating treatment efficacy during the late 1970 's ${ }^{(8)}$.

Several important characteristics of children with non-responsive Bitot's spots have been noted. One important observation is that the conjunctival tissue surround the lesion of non-responsive Bitot's spots is more characteristic of the histology of a vitamin $A$ replete child then of a vitamin $A$ deficient child $^{(9)}$. Serum vitamin A in children with nonresponsive Bitot's spots tends to be higher than in children with Bitot's spots that respond to therapy ${ }^{(10)}$. Children with Bitot's spots located in the nasal and temporal quadrant have a greater probability of responding to vitamin A therapy than children with Bitot's spots located in the temporal quadrants alone. Children with nonresponsive Bitot's spots have been observed to be older than children with responsive Bitot's spots. This characteristic suggests that children with non-responsive Bitot's spots are presenting a pathology associated with a previous episode of vitamin $A$ deficiency that has not healed after the acute phase of deficiency has passed ${ }^{(8)}$. However, this area has received only modest attention since early 1980's and little is known of other individual, household or community factors that might be associated with non-responsive Bitot's spots.

It was expected that many of the characteristics associated with responsive and non-responsive Bitot's spots in a clinical setting might also hold true in a community based field trial, even though the dosage was lower, and compliance was more difficult to ascertain. The importance of Bitot's spots as 
a primary indicator of vitamin A status warrants further exploration of the correlates of non-responsive Bitot's spots, in a field situation.

\section{MATERIALS AND METHODS}

From May through September 1989, a community ocular screening program for children under the age of 120 months was conducted for night blindness, Bitot's spots, and corneal manifestations of vitamin A deficiency by ophthalmic assistants in the central and west central regions of Nepal. Approximately 65,000 children in 289 randomly selected wards were examined in a survey as part of the baseline census for an intervention study comparing cost and impact of alternative approaches to control vitamin $A$ deficiency. After informed consent was obtained from the parent or guardian, a health history was taken; weight, height, and age were measured; and an eye exam was performed. The eyes were examined by an ophthalmic assistant using loupes and hand lights. The presence and location of the ocular eye signs were recorded. Conjunctival xerosis was considered an unreliable sign of vitamin A deficiency and was not recorded.

Children found with signs and symptoms of xerophthalmia were treated at the time of exam with 200,000 IU of vitamin $A$, and additional vitamin $A$ capsules were left with the mother along with instructions to dose the child again at 7,14 and 28 days after the initial capsule.

All study procedures were approved the Nepalese Ministry of Health, Nepal Netra Jyoti Sangh, and by the Human Subjects Committee of the School of Public Health of the University of Michigan. For this analysis, all children with Bitot's spots at baseline who were tracked over the subsequent 12 month period were analyzed to ascertain their xerophthalmic status.

The study included four distinct cohorts: in one cohort, the children received megadose vitamin A capsules semi-annually (Caps), another cohort of children received capsules, as well as selective elements of primary health care such as deworming. (PHC), a third group was exposed to nutrition education program without capsules (NutEd), and a control group (Control) the fourth group; in which only children ill during examination received capsules. More details on the study objectives and design are available elsewhere ${ }^{(11)}$.

With this design, approximately $50 \%$ of the children resided in villages assigned to receive capsules distributed twice a year. The remainder of the children did not have a chance to receive capsules unless they specifically went to the local health post and requested it.

The census and ocular exam were repeated again at 12 and 24 months by the same ophthalmic assistants. For a small sub sample of children in the survey, serum vitamin A was also measured. Three micropipettes of blood from finger pricks were collected. They were immediately stored at $3^{\circ} \mathrm{C}$, and sent to a central hospital in Bharatpur, where they were centrifuged, and the serum was stored at $-20^{\circ} \mathrm{C}$. Serum vitamin $A$ levels were determined by high performance liquid chromatography in the Agricultural Research Laboratories in Kathmandu, Nepal using standard procedures $^{(12)}$.

Nutritional status indicators were calculated according to standard procedures recommended by the World Health Organization, and cut off points for the classification of wasting, stunting and underweight were consistent with international procedures ${ }^{(13)}$.

The principle objective of the present analysis is to determine what characteristics distinguish children originally diagnosed with Bitot's spots who responded to vitamin $A$ supplementation (no longer had Bitot's spots) from those children who did not. Children are classified into one of four groups based on their follow-up ophthalmic examination:

Improved

Complete response (no X1B) Partical response (no X1B, but XN) 
Did not Improve

Non-responsive (X1B both years) Progressed (X2-X3B or died second year)

The students' t-test was used for comparing mean anthropometric values between groups, while categorical variables were compared using Pearson chi-square tests. Logistic regression models were developed to identify those characteristics which were associated with responsive and non responsive Bitot's spots. Associated odds ratios were calculated for independent variables after controlling for a number of potential cofounders. All data management was done using Foxpro for Windows ver. 2.6, and data analysis using SPSS for Windows ver 6.01

\section{RESULTS}

\section{Prevalence of Bitot's spots}

There were 689 children who were diagnosed with Bitot's spots at the time of the baseline survey. The prevalence among the children examined by the project $(n=54,080)$ is shown in Figure 1. At all ages except for year 1 (12-24 months) boys had a higher rate of Bitots spots than girls, with boys 1.74 times more likely to have Bitot's spots than girls. This was particularly pronounced in children older than 60 months. The peak prevalence of Bitot's spots was 7 years $(2.4 \%)$ for boys, and $4-5$ years $(1.6 \%)$ for girls.

\section{Impact of Program on Bitot's spots}

One year after the baseline exam, which was approximately 11 months after the interventions started, the 289 wards were visited again. Table 1 summarizes the baseline characteristics of the 689 children with Bitot's spots. Of these, all but 95 were identified again at the 12 month reexamination. Of those not examined, 37 were over the 120 month cut off for exam and were intentionally excluded from the study, the rest had migrated outside the study area or could not be found. Of the 587 that were reexamined, 383 of the children $(64.5 \%)$ had shown some improvement from the baseline examination; in 364 the Bitot's spots had disappeared, while 19 no longer had Bitot's spots, but were suffering from night blindness. In 193 children (32.5\%), Bitot's spots were still detected, in the same location with the same shape and size as baseline; 18 children had worsened (3.1\%), 13 had some type of active corneal sign at the 12 month follow-up, 2 had a corneal scar suggesting that in the preceding 12 months some episode of corneal xerophthalmia had followed the occurrence of the Bitot's spot, and 3 were known to have died.

\section{Individual Risk Factors}

The four groups of children (responded, improved, not responded, and worsened) were compared between baseline and after 12 months on several therapy for each characteristics such as age cohort, sex, nutritional status, number of vitamin $A$ capsule received and location of $\mathrm{X} 1 \mathrm{~B}$. The results are shown in Table 2.

Older children tended to respond the most to therapy with disappearing of symptoms, while girls who were more likely to respond than boys. However, the differences did not reach statistical significance.

Nutritional status was evaluated in several different ways. Children were categorized as wasted, stunted or underweight using both dichotomous cutoff's, and the Waterlow classification scheme. Using dichotomous categories, stunted children were more likely to respond to therapy, while no significant differences were seen by wasting or underweight status. The trend tended to be similar when using the Waterlow classification scheme, with stunted children having the highest rates of responsive Bitot's spots and wasted children having the lowest rates of responsive Bitot's spots. (Table 2). Interestingly, children that were both stunted and wasted had a better rate of responding to therapy and supplementation than 'normal' children. 


\section{Program Compliance}

The number of capsules received within the context of the intervention seemed to be associated with responsiveness. Those children in the two cohorts (Nuted, and Control) (See Table 5) where capsules were not distributed through the intervention still had a good rate of responding to the initial therapy that was given them after diagnosisas did the children that got two or more capsules beyond the dose received upon initial diagnosis (Table 2),. Children receiving only one capsule during the intervention had the lowest rates of responsive Bitot's spots, and the highest rate of non-responsive Bitot's spots.

\section{Location of Bitot's spots}

Bitot's spots are seen either in both eyes, or in a single eye. Sometimes they appear in both the nasal and temporal quadrant, but most often they appear only in the temporal quadrant. Although most Bitot's spots in children occur bilaterally, some are unilateral, while only a very few are unilateral which manifest in both the temporal and nasal quadrants. In this study, most of the chldren had two Bitot's spots. Interestingly, among children who had 1, 3 and 4 lesions, the chance of responding was significantly greater than children with 2 lesions (Table 3a) $(R R=1.14 ; 95 \%$ confidence interval $(1.05,1.23)$. Temporal Bitot's spots were less responsive than Bitot's spots occuring in both nasal and temporal quadrants. (Table 2).

In Table 4 different continuous individual characteristics are compared. For this analysis the response categories are collapsed into two groups: those that improve (or responded), and those that did not respond (or got worse). Those that improved were slightly older although not significant so there was no difference in weight for age between those that responded and those that did not. Weight-for-height (WFH), which was not significant as a categorical variable (wasting) in explaining the response of the ocular lesion to therapy and dietary supplementation after twelve months did render statistical significance when treated as a continuous variable, with a 0.25 S.D. difference in WFH levels between those that responded and those that did not respond. Height-for-age (HFA) (stunting) which was one of the most important characteristics when dichotomized was also found to be significant on a continuous scale with children who responded having HFA levels which were 0.36 S.D. lower than those with Bitot's spots that did not respond. Mid upper arm circumference (MUAC), triceps skinfold, and serum retinol (from the small subsample for which blood information was available) were not significantly different between children with responsive and non responsive Bitot's spots.

\section{Community Risk Factors}

While individual characteristics provide some insight as to which children respond to therapy and which do not, certain community characteristics appear to be also associated with non responsiveness (Table 5). Children in the semi-annual capsule cohort of the study (VAC) had the highest response rate to therapy and supplementation. Children getting deworming along with their capsules had the lowest rates of Bitot's spots responding to therapy and dietary supplementation. Children in the two cohorts not receiving capsules as a part of their intervention had similar rates of responsiveness.

Community characteristics which were related to responsiveness included; district that the child resided in and the terrain type of the district. Children in Parsa District had very high rates of non-responsiveness to therapy, while almost all the children in Chitawan responded to therapy. The response rate was also low in Nawalparasi, and was similar in Bara, Makwanpur, and Tanahu. Difference of racial distribution by terrain type found in these districts may help to explain this observation. Parsa, with the very high non-responsive rate, is in the Terrai, located nearby, and in the same ecological zone as Bara that tended to have response rates similar to the hill areas of the 
study. Chitawan which had the highest rates of Bitot's spots responding to therapy is mixed terrain, but most of its population lies in the Terrai.

\section{Logistic Regression Analysis}

The final analysis (Table 6) was to develop a series of logistic regression models to explain the effects of certain of factors in predicting Bitot's spots response to therapy. Different combinations of categorycal and continuous variables were used to develop models to predict nonresponsiveness.

Table 6A shows the results of logistic regression for all children with Bitot's spots. Children in the semi-annual capsule group had the highest rate of responsivness of Bitot's spots. This suggests that the responsiveness of Bitot's spots to therapy after assessment, also depends very much on whether or not the child continues to get capsules from the community intervention. The terrain (terrai versus the hills) was also associated with non-responsive Bitot's spots with children in the Terrai being $43 \%$ more likely to have a non-responsive Bitot's spots than a child from the hill area.

Individual variables within the model included, the location of Bitot's spots on the conjunctiva, the number of capsules received, MUAC, and gender. If Bitot's spots appeared in the temporal quadrant alone, then the child was less likely to respond to therapy. It was observed that males are about $20 \%$ more likely to have a nonresponsive Bitot's spots than a female. Some of the factors which did not remain in the model were age, triceps skinfold thickness, weight for age, height for age, weight for height, or the Waterlow classification of the child's nutritional status.

It appeared that different patterns of non-responsiveness occured in different populations as defined by community and individual level characteristics. To test this assumption, logistic regression models were examined for children stratified by terrain and age. In the Terrai (Table 6B), the pattern of risk was complicated, with the intervention the individual was exposed to, the number of capsules received, the location of the Bitot's spot, the gender, and the MUAC score all being associated with the responsiveness of the Bitot's spots. For children in the hills (Table $6 \mathrm{C}$ ), the logistic regression only identified weight for age as being important in predicting the risk of non-responsive Bitot's spots. Among the hill children for each standard deviation improvement in weight for age, there was a $62 \%$ reduced likelihood of having a non-responsive Bitot's spots.

For children under 60 months of age (Table 6D), the location of the Bitot's spots was very important and was the only variable which was significant in the model. Those children with only temporal lesions had a $97 \%$ greater probability of nonresponsiveness. However, for children over 60 months of age (Table 6E), location of the Bitot's spot was not as important, but the intervention activities which the child was exposed to and the frequency of mega dose supplementation were all included in the predictive model (Table 6E). In addition, males had a higher chance of nonresponsiveness than females, as did the children 6-7 years of age when compared to 9-10 years of age. More importantly, indicators of nutritional status were also selected as important with MUAC, triceps skinfold thickness, height for age, and weight for height all being associated with responsiveness. Children that were wasted had a greater likelihood of having nonresponsive Bitot's spots, while children that were stunted, more likely to respond to therapy and dietary supplementation and not have Bitot's spots at the second measurement.

\section{DISCUSSION}

It appears that the majority of children with Bitot's spots seen in a field situation disappear after therapy and a year of participation in an intervention program. The nature of Bitot's spots that responded to therapy appears to be generally quite similar 
in both clinical and field settings, even though the dosage, and the follow-up time is not. The responsiveness of Bitot's spots under field conditions depended on individual factors, the nature of the intervention, as well as community level factors.

\section{Individual level factors - location of lesion.}

The observation from Indonesia in 1980 that Bitot's spots were more likely to respond to therapy if they occurred temporally and nasally appear to hold true for children in Nepal. This factor was identified in the logistic regression analysis for the general population as being significant, but was particularly important in children under 60 months of age. Clinical observations from Indonesia in $1991{ }^{(7)}$ that children with 4 Bitot's spots had a lower 5 week cure rate than children with 2 Bitot's spots did not appear to be the case during a 12 month follow-up period in Nepal. Children with 4 Bitot's spots at baseline were found to be more likely to respond to therapy and dietary supplementation than children with just two Bitot's spots, just as was found in 1980 in Indonesia ${ }^{(9)}$.

\section{Individual level factor - age}

In Nepal, the risk for Bitot's spots was higher among children between $60-120$ months. Generally, the importance of Bitot's spots in this age cohort is discounted because it is assumed that children will most likely have non-responsive Bitot's spots. This clinical assumption did not appear to be the case for children in this study. In fact, the mean age of children with non-responsive Bitot's spots was lower by 4 months although this was not significant (Table 3). It was also noted in bivariate analysis that the group with highest level of responsiveness to vitamin $A$ was among children aged 8 - 10 years.

In addition, the logistic regression did not identify the age variable as being significantly associated with nonresponsiveness. However, it was noted that children of different ages have distinct patterns of risk. Young children's non- responsive Bitot's spots were associated with the location of the lesion (temporally as compared to a nasal/temporal location). Among older children, a number of factors also seem to play a role in predicting risk including the intervention the child is exposed to their gender, and nutritional status.

\section{Individual level factor - nutritional status}

Nutritional status appears to play a role in the risk of non-responsive Bitot's spots. Wasting appears to increase the probability of non-responsive Bitot's spots, while stunting appears to be associated with decreased risk for non-responsive Bitot's spots. Small children that have adequate weight for height are less likely to have nonresponsive Bitot's spots than taller children with a lower body mass. Nutritional status appears to be the most important variable for children over 60 months, and for children living in the hill areas.

\section{Intervention level factor - dosage}

The observation that more nonresponsive Bitot's spots were seen among children receiving a smaller annual supplementation dose, as compared to a larger dose ${ }^{(10)}$ also appears to be borne out by this analysis. Children in the capsule cohort that had at least two capsules appeared to have a much lower nonresponsive rate than children that were not exposed to the capsule intervention program, or who only got one capsule. It also appears that children that were dewormed immediately before they received their vitamin A capsule had an increased rate of non-responsive Bitot's spots.

\section{Community level factor - terrain}

The risk of Bitot's spots was generally much lower in the hill area than the terrai. There are two different major racial groups in Nepal; Asian and Caucasian. While not universally true the hills are predominately the domain of the Asian stocks, while the Terrai is the domain of the Caucasian population. Risk among the population in the 
hill areas for non responsive Bitot's spots were generally associated with low weight for age, while for the Terai villages, exposure to invention, location of the Bitot's spot, and dosage all seemed to plan important roles in determining risk

\section{CONCLUSION}

The major difference in this study and other studies that have looked at nonresponsive Bitot's spots is that the other efforts that looked at non-responsive Bitot's spots were based out of Eye Hospitals. Being clinic based studies, excellent followup in the short run was possible, as was strict compliance to a treatment regime, follow-up rates were generally above $90 \%$.

The Vitamin A Child Survival Project in Nepal was not a controlled clinical trial nor a clinic based study, but an operations research study. The major end point of interest was program participation, associated improvements in health status, and cost of the interventions. To ascertain this, three annual census were carried out. The sample was very large, and funds limited so that no follow-up of xerophthalmic children was done after the team left the survey site until the following year. It is therefore impossible to see if those children that had non-responsive Bitot's spots 12 months after the baseline exam, had in fact been 'cured' for a while, and then had the lesion reoccur at some later date.

However, in general, the picture developed for young children in a clinical setting appears to generally be true. Dr. Semba (1990) talks about a persistence of Bitot's spots in about a quarter of the preschool children after dosage with 200,000 IU of oral vitamin A. We found a persistence of about $35 \%$ among children aged 6 - 120 months, one year after the initial diagnosis, with each of the children receiving immediate therapy upon diagnosis, and $50 \%$ of them receiving some additional type of mega dose capsule supplementation.
We did not find age to be particularly important in determining risk for nonresponsive Bitot's spots, but did find that dosage, sex of the child, location of the Bitot's spots, terrain in which the child lived, and the nutritional status to be primary predictors of risk for non-responsive Bitot's spots. We did find that age discriminated patterns of risk, with young children having nasal and temporal Bitot's spots being more likely to respond to therapy, and older children's risk being more affected by dosage, and nutritional status.

Non responsive Bitot's spots are not a phenomena limited to older children, but rather it is seen in all age groups. However, just as the pattern of risk varies between terrain type within Nepal, it is expected that it will also vary from country to country as risk factors, and community dynamics producing vitamin A vary. These variations need to be acknowledged and accommo-dated when using Bitot's spots as indicators of the magnitude of risk among communities.

\section{REFERENCES}

1. Paton, D., McLaren, D.S.(1960); "Bitot's spots." Am J Ophthalmol 50:568.

2. McCollum EV, Simmonds N. (1917); "A Biological Analysis of Pelegria producing diets. II. the minimum requirements of the two unidentified dietary factors for maintenance as contrasted with growth" The Journal of Biological Chemistry Vol XXXII, No. 2 181-94.

3. Sommer, Tarwotjo I, Hussaini G, and Susanto D. "Increased mortality in children with mild vitamin A deficiency" Lancet 2:585, 1983.

4. Sommer A, Katz J, Tarwotjo I. (1984) "Increased risk of 
respiratory disease and diarrhea in children with pre-existing vitamin A deficiency" Am J Cln Nutr 40:1990.

5. United National International Emergency Fund (UNICEF). The Progress of Nations. New York: UNICEF, 1994.

6. World Health Organization; "Joint WHO/UNICEF Consultation on Vitamin A indicators, Indicators for Assessing Vitamin A Deficiency and their Application on Monitoring and Evaluating Programmes". Review version - WHO/NUT/94.1 Geneva: World Health Organization 1994.

7. Semba RD, Wirasamita S, Natadisastra, G, Muhilal, Sommer A. (1990); "Response of Bitot's spots in Preschool Children to Vitamin A treatment" American Journal of Ophthalmology 110:416-20.

8. Sommer A, Emran N Tjakrasudjatma S. (1980) "Clinical characteristics of vitamin A responsive and nonresponsive Bitot's spots" American Journal of Ophthalmology 99:160-71.

9. Sommer A, Green WR, Kenyon KR. (1981); "Bitot's spots responsive and non-responsive to vitamin A. Clinicopathologic correlations" Arch Ophthalmol. 99:2014-27.

10. Sovani I, Humphrey JH, Kuntinalibronto DR, Natadisastra G, Muhilal, Tielsch J (1994) "Res ponse of Bitot's spots to a single oral 100,000 or 200,000 IU Dose of vitamin A." Amer $\mathrm{J}$ of Ophth 118:792-96.

11. University of Michigan, Department of International Health and Population 1993. "Final Report: Vitamin A Child Survival Program". Ann Arbor.

12. Arroyave G, Chichester $\mathrm{CO}$ Flores $\mathrm{H}$, Glover J, Mejia LA, Olson $\mathrm{JA}$, Simpson $\mathrm{KL}$, and Underwood BA. Biochemical methodology for the assessment of vitamin A status. Report of the International Vitamin A consultative Group (IVACG) Washington, D.C., the Nutrition Foundation, 1982, pg 92.

13. Gorstein J, Sullivan K, Yip R, de Onis $M$, Trowbridge $F$, Fajans $P$, Clugston G, ( 1994); "Issues in the assessment of nutritional status using anthropometry." Bull World Health Organ, 72(2):273-83. 


\section{Acknowledgments:}

This study was a collaborative project undertaken by Nepal Netra Jyoti Sangh, a Nepalese voluntary blindness prevention organization and the Department of Population Planning and International Health, University of Michigan. Financial support was received from UNICEF and the Office of International Health in the Department of Health and Human Services (HHS); US Government. The funds for UNICEF originated with the Government of Italy's Joint Nutrition Support Program, and the funds for the HHS originated from the Nutritional Desk of the United States Agency for International Developments Asia Near East Section. Support was also received from The Duluth Clinic, Duluth, Minnesota. Several hundred individuals helped develop, implement, and evaluate these programs, and while their selfless contributions are gratefully acknowledged, we will focus on the primary members of the Vitamin A Child Survival Project, which include the team leaders: Bhola Siwakoti, Bnod Bista, Keehab Sharma, Bhawani Pant, Hari Ghimire, Harka Bdr. Thapa, Bhogendra Limbu, Gyan Bdr. Bhujel. In addition there are other members of the support staff which should also be mentioned, and they include, Filippo Curtale, Suzinne, Pak, Jim Lepkowski, Mary Bannister, Norman Starr, Anna Schmitz-Erpelding, Kate Colson, Debbie Humphries, Muhilal, Atmarita, and Barbara Underwood. There are several hundred more individuals that were associated with and participated in the vitamin A Child Survival Project, but they cannot all be cited here due to lack of space. Their hard work and selfless service is gratefully acknowledged and appreciated.

Table 1

Follow-up Children with Bitot's Spots at Baseline ( $\mathrm{n}=689)$ - Nepal VACSP

\begin{tabular}{|c|c|c|c|}
\hline & $\mathrm{n}$ & $\%$ of all cases & $\begin{array}{l}\% \text { of cases } \\
\text { followed-up }\end{array}$ \\
\hline \multicolumn{4}{|l|}{ Responded (383) } \\
\hline Cured & 364 & 52.8 & 61.3 \\
\hline Improved (to XN) & & 19 & 2.8 \\
\hline 3.2 & & & \\
\hline Non-response (195) & 193 & 28.0 & 32.5 \\
\hline \multicolumn{4}{|l|}{ Worsened (18) } \\
\hline Developed corneal sign & 13 & 1.9 & 2.2 \\
\hline Developed corneal scar & 2 & 0.3 & 0.3 \\
\hline Died & 3 & 0.4 & 0.5 \\
\hline Lost to follow up * & 95 & 13.0 & \\
\hline
\end{tabular}

${ }^{*}$ Of those children lost to follow-up, 37 (39.0\%) were above 120 months at the time of the second measurment and therefore were no longer included in the study. The remainder were not identified by the field teams and consequently were eliminated (censored) from the study. 
Table 2

Children with Bitot's Spots at Baseline who were followed Individual Characteristics $(n=587)$

\begin{tabular}{|c|c|c|c|c|c|c|}
\hline Variabels & $\mathrm{n}(\%)$ & $\begin{array}{c}\text { Responded } \\
\%\end{array}$ & $\begin{array}{c}\text { Improved } \\
\%\end{array}$ & $\begin{array}{c}\text { Not } \\
\text { responded \% }\end{array}$ & $\begin{array}{c}\text { Worsened } \\
\%\end{array}$ & $\square^{2} p$ \\
\hline $\begin{array}{l}\text { Age (years) } \\
0-2.9 \\
3-4.9 \\
5-7.9 \\
8-10.9\end{array}$ & $\begin{array}{c}33 \\
140 \\
282 \\
132\end{array}$ & $\begin{array}{l}57.6 \\
62.1 \\
58.2 \\
67.4\end{array}$ & $\begin{array}{l}3.0 \\
0.7 \\
3.5 \\
4.5\end{array}$ & $\begin{array}{l}33.3 \\
35.0 \\
34.8 \\
25.8\end{array}$ & $\begin{array}{l}6.1 \\
2.1 \\
3.5 \\
2.3\end{array}$ & 0.40 \\
\hline $\begin{array}{l}\text { Sex } \\
\text { Boys } \\
\text { Girls } \\
\end{array}$ & $\begin{array}{l}375 \\
212 \\
\end{array}$ & $\begin{array}{l}57.9 \\
67.0 \\
\end{array}$ & $\begin{array}{l}3.7 \\
1.9 \\
\end{array}$ & $\begin{array}{l}35.2 \\
28.3 \\
\end{array}$ & $\begin{array}{l}3.2 \\
2.8 \\
\end{array}$ & 0.14 \\
\hline $\begin{array}{l}\text { Nutritional Status } \\
\text { Wasted } \\
\text { Not Wasted }\end{array}$ & $\begin{array}{l}262(47.5) \\
290(52.5)\end{array}$ & $\begin{array}{l}58.0 \\
65.2\end{array}$ & $\begin{array}{l}3.1 \\
2.8\end{array}$ & $\begin{array}{l}35.5 \\
29.3\end{array}$ & $\begin{array}{l}3.4 \\
2.8\end{array}$ & 0.39 \\
\hline $\begin{array}{l}\text { Stunted } \\
\text { Not Stunted }\end{array}$ & $\begin{array}{l}302(52.3) \\
275(47.7)\end{array}$ & $\begin{array}{l}65.6 \\
57.1\end{array}$ & $\begin{array}{l}3.0 \\
3.3\end{array}$ & $\begin{array}{l}27.5 \\
37.5\end{array}$ & $\begin{array}{l}4.0 \\
2.2\end{array}$ & .05 \\
\hline $\begin{array}{l}\text { Underweight } \\
\text { Not Underweight }\end{array}$ & $\begin{array}{l}419(72.0) \\
163(28.0)\end{array}$ & $\begin{array}{l}60.6 \\
62.0\end{array}$ & $\begin{array}{l}3.6 \\
1.8\end{array}$ & $\begin{array}{l}32.7 \\
33.1\end{array}$ & $\begin{array}{l}3.1 \\
3.1\end{array}$ & 0.76 \\
\hline $\begin{array}{l}\text { Normal } \\
\text { Stunted along } \\
\text { Wasted along } \\
\text { Stunted and Wasted }\end{array}$ & $\begin{array}{l}113(20.7) \\
174(31.9) \\
145(26.6) \\
114(20.9) \\
\end{array}$ & $\begin{array}{l}60.2 \\
69.0 \\
54.5 \\
62.3 \\
\end{array}$ & $\begin{array}{l}0.9 \\
4.0 \\
4.8 \\
0.9 \\
\end{array}$ & $\begin{array}{l}36.3 \\
24.1 \\
38.6 \\
31.6 \\
\end{array}$ & $\begin{array}{l}2.7 \\
2.9 \\
2.1 \\
5.3 \\
\end{array}$ & 0.5 \\
\hline \multicolumn{7}{|c|}{ Number of VAC Received after Initial Treatment } \\
\hline $\begin{array}{l}0 \\
1 \\
2 \\
3-4 \\
\end{array}$ & $\begin{array}{c}292(50.2) \\
82(14.1) \\
157(27.0) \\
51(8.8)\end{array}$ & $\begin{array}{l}63.4 \\
54.9 \\
59.2 \\
64.7\end{array}$ & $\begin{array}{l}2.1 \\
8.5 \\
1.9 \\
3.9\end{array}$ & $\begin{array}{l}31.8 \\
30.5 \\
36.9 \\
31.4\end{array}$ & $\begin{array}{l}2.7 \\
6.1 \\
1.9 \\
0.0\end{array}$ & 0.5 \\
\hline \multicolumn{7}{|l|}{ Location of X1B } \\
\hline $\begin{array}{l}\text { Temporal } \\
\text { Nasal\&Temporal }\end{array}$ & $\begin{array}{c}484(86.6) \\
75(13.4) \\
\end{array}$ & $\begin{array}{l}58.5 \\
76.0 \\
\end{array}$ & $\begin{array}{l}3.3 \\
2.7 \\
\end{array}$ & $\begin{array}{l}34.9 \\
18.7 \\
\end{array}$ & $\begin{array}{l}3.3 \\
2.7 \\
\end{array}$ & $<0.05$ \\
\hline
\end{tabular}


Table 3

Number of Bitot's Spots and Outcome of Treatment in 12 months

\begin{tabular}{|c|c|c|c|}
\hline Number of Bitot's spots & Number of Children & $\begin{array}{c}\text { Improve /Responded } \\
(\%)\end{array}$ & $\begin{array}{c}\text { No Response / } \\
\text { Worsened (\%) }\end{array}$ \\
\hline 1 & 50 & $36(72.0)$ & $14(28.0)$ \\
2 & 473 & $291(61.5)$ & $182(38.5)$ \\
3 & 31 & $25(80.6)$ & $6(19.4)$ \\
4 & 40 & $31(77.5)$ & $9(22.5)$ \\
& Value & DF & Sig \\
Person Chi-square & 9.54 & 3 & 0.023 \\
Mantel-Haenszel & 0.089 & 1 & 0.112 \\
\hline
\end{tabular}

Table $3 \mathrm{~A}$

\begin{tabular}{|c|c|c|c|}
\hline $\begin{array}{c}\text { Number of } \\
\text { Bitot's spots }\end{array}$ & $\begin{array}{c}\text { Number of } \\
\text { Children }\end{array}$ & $\begin{array}{c}\text { Improve / } \\
\text { Responded (\%) }\end{array}$ & $\begin{array}{c}\text { No Response / } \\
\text { Worsened (\%) }\end{array}$ \\
\hline 1,3 or 4 & 121 & $92(76.0)$ & $31(24.0)$ \\
2 & 473 & $291(61.5)$ & $182(38.5)$ \\
& Value & DF & Sig \\
Person Chi-square & 5.02 & 1 & 0.003 \\
Mantel-Haenszel & 5.01 & 1 & 0.003 \\
\hline
\end{tabular}

Relative Risk for No Response 2 vs 1,3 or $4=1.14$

Taylor Series 95\% Confidence Interval $=(1.05<R R<1.23)$

Table 4

Children with Bitot's Spots at Baseline who were followed Individual Characteristics $(n=587)$

\begin{tabular}{|l|c|c|c|}
\hline Indicator & $\begin{array}{c}\text { Improved } \\
\text { /Responded }\end{array}$ & $\begin{array}{c}\text { No response / } \\
\text { Worsened }\end{array}$ & $\begin{array}{c}\text { t-test } \\
\text { D-value }\end{array}$ \\
\hline Age - (months) & $73.1(25.2)$ & $69.8(23.9)$ & 0.11 \\
Weight -Age - (Z-score) & $-2.58(1.05)$ & $-2.58(1.19)$ & 0.98 \\
Weight -Height - (Z-score) & $-1.74(1.09)$ & $-2.01(1.04)$ & $<0.01$ \\
Height-Age - (Z-score) & $-2.17(1.72)$ & $-1.81(1.74)$ & $<0.05$ \\
MUAC - (cm.) & $14.37(1.38)$ & $14.29(1.45)$ & 0.49 \\
Triceps skinfold - (cm2) & $5.99(3.36)$ & $6.04(1.82)$ & 0.85 \\
Serum Retinol - (ug/dl) & $14.92(9.41)$ & $16.01(9.76)$ & 0.81 \\
\hline
\end{tabular}


Table 5

Children with Bitot's Spots at Baseline who were followed

Community / Ecological Characteristics $(n=587)$

\begin{tabular}{|l|c|c|c|c|c|c|}
\hline & $\mathrm{n}(\%)$ & Responded & Improved & $\begin{array}{c}\text { Not } \\
\text { responded }\end{array}$ & Worsened & [2 P \\
\hline Intervention & $129(22.0)$ & 75.2 & 1.6 & 20.9 & 2.3 & $<0.01$ \\
VAC & $161(27.4)$ & 49.1 & 6.2 & 40.4 & 4.3 & \\
PHCCAP & $118(20.1)$ & 61.0 & 0.8 & 34.7 & 3.4 & \\
NUTPHC & $179(30.5)$ & 62.0 & 2.8 & 33.0 & 2.2 & \\
SYMPT & & & & & & \\
& & & & & & \\
District & $179(30.5)$ & 71.5 & 3.9 & 22.9 & 1.7 & $<0.001$ \\
Bara & $234(39.9)$ & 47.4 & 2.6 & 46.6 & 3.4 & \\
Parsa & $20(3.4)$ & 75.0 & 10.0 & 15.0 & 0.0 & \\
Makwanpur & $25(4.3)$ & 92.0 & 4.0 & 4.0 & 0.0 & \\
Chitawan & $89(15.2)$ & 59.6 & 0.0 & 36.0 & 4.5 & \\
Nawalparasi & $27(4.6)$ & 74.1 & 7.4 & 14.8 & 3.7 & \\
Tanahu & $13(2.2)$ & 69.2 & 0.0 & 15.4 & 15.4 & \\
Palpa & & & & & & \\
& & & & & & \\
Terrain & $528(89.9)$ & 59.5 & 2.8 & 34.8 & 2.8 & $<0.01$ \\
Terrai & $59(10.1)$ & 76.3 & 5.1 & 13.6 & 5.1 & \\
Hills &
\end{tabular}

Table 6

Results of Logistic Regression Analysis

Table 6-A

All Bitot's Spots

$\llbracket 2=50.78$ d.f. $\quad$ Sig $<0.0000$

\begin{tabular}{|l|c|c|c|}
\hline \multicolumn{1}{|c|}{ Variables included in model } & Sig. & $\mathbf{R}$ & O.R. \\
\hline Exposure to Intervention & 0010 & .1087 & \\
Capsule compared to control & .0001 & -.1228 & 0.4652 \\
PHC compared to controls & 2076 & .0000 & 1.2195 \\
Nut Ed compared to controls & .1361 & .0159 & 1.2952 \\
Terrain (Terrai vs hills) & 0235 & .0598 & 1.4323 \\
Location of Bitot's Spots (Temporal only vs temporal \& Nasal) & .0180 & .0641 & 1.3957 \\
Sex (male vs. Female) & .0362 & .0522 & 1.2049 \\
Muac at baseline (continuous) & .0067 & .0782 & 0.9841 \\
At least two Capsules received from intervention & .0049 & -.0823 & 0.7158 \\
\hline
\end{tabular}

Variables not included (controlled for in model)

Age (continuous)

Triceps skinfold 
Weight-for-Age (Underweight)

Height-for-Age (Stunting)

Weight-for height (Wasting)

Age of child (categorized above and blow 60 mon.)

Waterlow nutritional status classification)

At least one Capsule receive from intervention

Table 6-B

Terai Villages

$$
\llbracket 2=36.4
$$

7 d.f.

Sig $<0.0000$

\begin{tabular}{|l|c|c|c|}
\hline Variables included in model & Sig. & $\mathrm{R}$ & $\mathrm{O} . \mathrm{R}$. \\
\hline Exposure to Intervention & .0059 & .0904 & \\
Capsule compared to control & .0007 & -.1098 & 0.4983 \\
PHC compared to controls & .2613 & .0000 & 1.1992 \\
Nut Ed compared to controls & .2348 & .0000 & 1.2389 \\
Location of Bitot's Spots (temporal only vs temporal \& nasal) & .0143 & .0711 & 1.4549 \\
Sex (male vs female) & .0362 & .0522 & 1.2049 \\
Muac at baseline (continuous) & .0067 & -.0782 & 0.9841 \\
At least two Capsules received from intervention & .0049 & -.0823 & 0.7158 \\
\hline
\end{tabular}

All others listed above in A. Not included in model

Table 6-C

Hill Villages

$$
\llbracket 2=5.761 \text { d.f. } \quad \text { Sig }<0.0164
$$

\begin{tabular}{|l|l|l|l|}
\hline \multicolumn{1}{|c|}{ Variables included in model } & \multicolumn{1}{|c|}{ Sig. } & R. & O.R. \\
\hline Weight for Age & .0291 & -.1945 & 0.3874 \\
\hline
\end{tabular}

All others listed above in A. Not inclued in this model

Table 6-D

Children $<60$ months old

$02=7.8 \quad 1$ d.f. $\quad$ Sig $<0.0050$

\begin{tabular}{|l|l|l|l|}
\hline Variables included in modeL & Sig. & R & O.R. \\
\hline $\begin{array}{l}\text { Location of Bitot's Spot } \\
\text { (temporal only vs temporal \& nasal) }\end{array}$ & .0139 & .1125 & 1.9788 \\
\hline
\end{tabular}

All others listed above in A. Not included in this model

Table 6-E

Children > 60 months old

$\llbracket 2=36.47$ d.f. $\quad$ Sig $<0.0000$ 


\begin{tabular}{|l|c|c|c|}
\hline Variables included in model & Sig. & $\mathrm{R}$ & O.R. \\
\hline Exposure to intervention & $.0392^{\circ}$. & 0652 & \\
Capsule compared to control & .0130 & -.0867 & 0.5411 \\
PHC compared to controls & $.1406^{\circ}$ & .0176 & 1.3602 \\
Nut Ed compared to controls & $.356^{\circ}$. & 0000 & 1.2360 \\
Sex (males vs female) & $.0093^{\prime}$ & -.0928 & 1.3743 \\
Age & .0237 & -.0750 & 0.9836 \\
Triceps Skinfold thickness & $.0479^{\circ}$ & .0588 & 1.1268 \\
Muac at baseline (continuous) & .0163 & -.0728 & 0.8624 \\
Height for age & $.0023^{\circ}$ & .1148 & 1.2160 \\
Weight for Height & .0412 & -.0625 & 0.8796 \\
At least two capsules received from intervention & .0118 & -.0885 & 0.6722 \\
\hline
\end{tabular}

All others listed above in A. Not included in this 